\title{
Muscle and biomechanical response time in patrol horses submitted to functional
}

\section{training}

\author{
Tempo de resposta muscular e biomecânica em cavalos de patrullhamento submetidos a exercícios \\ funcionais
}

Tiempo de respuesta muscular y biomecánica en caballos patrulla sometidos a entrenamiento

\section{funcional} Universidade Estadual Paulista, Brasil

E-mail: katia.oliveira@unesp.br

Stéphanie de Souza Vitório Alves

ORCID: https://orcid.org/0000-0002-5859-2470 Universidade Federal de Sergipe, Brasil

E-mail: stephanie.vet@outlook.com

Camila Fernanda Fidêncio

ORCID: https://orcid.org/0000-0001-5437-7995 Universidade Federal de Sergipe, Brasil

E-mail: camilaferf@gmail.com

Clístenes Gomes de Oliveira

ORCID: https://orcid.org/0000-0002-1874-9613 Universidade Federal de Sergipe, Brasil

E-mail: clismedvet80@hotmail.com

Lahesgyla Nascimento Fontes

ORCID: https://orcid.org/0000-0002-3034-9348 Universidade Federal de Sergipe, Brasil E-mail: lahesgylafontes@hotmail.com

José Miradelson Oliveira Carvalho

ORCID: https://orcid.org/0000-0002-4911-635X Universidade Federal de Sergipe, Brasil

E-mail: miradelsoncarvalho@outlook.com

Camilla Mendonça Silva

ORCID: https://orcid.org/0000-0001-7391-272X Universidade Federal de Sergipe, Brasil

E-mail: camillamsazoo@gmail.com

Anselmo Domingos Ferreira Santos

ORCID: https://orcid.org/0000-0002-9041-4308 Universidade Federal de Sergipe, Brasil

E-mail: anselmodfsantos@yahoo.com.br

\begin{abstract}
Physical activities frequency and intensity performed by equine, athletes or workers, have been growing significantly enabling appearance of musculoskeletal disorders. Thus, the objective of this research was to evaluate the effect of a functional training program to measure short-, medium- and long-term response on epaxial musculature development, as well in linear kinematics of patrol horses. Eight $14 \pm 3.5$ years-old horses, weighing $418 \pm 50 \mathrm{~kg}$, were evaluated over a 90 days period to divided in short (30 days), medium (60 days) and long (90 days) responses. All horses were submitted to the same FTP consisting of passive stretching exercises, dynamic mobilization, reflexive mobilization and dynamic imbalance. The monitored traits were the Longissimus dorsi (LD) muscle thickness; the Musculus multifidus (MM) total cross-sectional muscle area; linear kinematic analysis through the stride length at walk (LSW) and trot (LST). The thickness of the right and left side-LD showed increase at 90-day of the training period. The MM total cross-sectional area increased progressively after 30 days on both sides of the body, and at end of the 90-day evaluation. LSW and LST increased after 60 days of training. It is concluded for short-term; exercises promoted the hypertrophy of Musculus
\end{abstract}


multifidus; for medium-term, increased the stride length and, and for long-term, hypertrophy of the Longissimus dorsi was observed.

Keywords: Stretching; Kinematics; Muscle hypertrophy; Dynamic mobilization.

\section{Resumo}

A frequência e intensidade das atividades executadas pelos equinos atletas ou de trabalho vêm crescendo significativamente, predispondo os animais a desordens musculoesqueléticas. Assim, objetivou-se avaliar o efeito de um programa de exercícios funcionais, ao longo de 90 dias, para mensurar o tempo de resposta a curto, médio e longo prazo sobre o desenvolvimento da musculatura epaxial e cinemática linear de equinos de patrulhamento. Oito cavalos foram avaliados ao longo de 90 dias para determinação de respostas a curto (30 dias), médio (60 dias) e longo (90 dias) prazo. Todos os cavalos foram submetidos a um programa de treinamento funcional que consistiu em exercícios de alongamento passivo, mobilização dinâmica, mobilização reflexiva e desequilíbrio dinâmico. Foram monitoradas a espessura do músculo Longissimus dorsi (LD) e a área total transversal do Musculus multifidus (MM), e análise cinemática linear por meio do comprimento da passada ao passo (CPP) e ao trote (CPT). A espessura do LD aumentou 90 dias após início dos exercícios funcionais, tanto no lado esquerdo quanto direito do corpo dos animais. A área transversal total do MM apresentou aumento significativo e progressivo a partir de 30 dias, em ambos os lados do corpo, e ao longo de todo os 90 dias de avaliação. O CPP e CPT aumentaram a partir 60 dias. Conclui-se que, os exercícios funcionais promovem, a curto prazo, a hipertrofia do Musculus multifidus, a médio prazo, incremento no comprimento da passada e, a longo prazo, hipertrofia do Longissimus dorsi.

Palavras-chave: Alongamento; Cinemática; Hipertrofia muscular; Mobilização dinâmica.

\section{Resumen}

La frecuencia e intensidad de las actividades realizadas por los caballos de trabajo y de deporte han ido aumentando de forma significativa, predisponiendo a los animales a sufrir trastornos musculoesqueléticos. Así, el objetivo fue evaluar el efecto de un programa de ejercicio funcional, durante 90 días, para medir el tiempo de respuesta a corto, mediano y largo plazo sobre el desarrollo de la musculatura epaxial y la cinemática lineal de los caballos patrulla. Se evaluaron ocho caballos durante 90 días para determinar respuestas cortas (30 días), medianas (60 días) y largas (90 días). Todos los caballos se sometieron a un programa de entrenamiento funcional que consistió en ejercicios de estiramiento pasivo, movilización dinámica, movilización reflexiva y desequilibrio dinámico. Se monitorizó espesor del músculo Longissimus dorsi (LD) y el área transversal total de Musculus multifidus (MM) y se realizó un análisis cinemático lineal mediante longitud al paso (LP) y trote (LT). El espesor de la LD aumentó 90 días después del inicio de los ejercicios funcionales, tanto en el lado izquierdo como derecho del cuerpo de los animales. El área transversal total del MM mostró un aumento significativo y progresivo después de 30 días, en ambos lados del cuerpo y durante los 90 días completos de evaluación. LP y LT aumentaron después de 60 días. Se concluye que, a corto plazo, los ejercicios funcionales favorecen la hipertrofia de Musculus multifidus, a medio plazo, aumento de la longitud al paso y, a largo plazo, hipertrofia de Longissimus dorsi.

Palabras clave: Extensión; Cinemática; Hipertrofia muscular; Movilización dinámica.

\section{Introduction}

Since the origin of animal domestication, horses have been increasingly required to perform many different types like sports and work (Cabral et al., 2020). As result, physical activities frequency and intensity performed by these animals has grown significantly, allowing the musculoskeletal disorders (Aleman, 2008; Ropka-Molik et al., 2017).

Among these disorders, those affecting the thoracolumbar region should be observed carefully, as they are largely considered responsible for athletic performance reduction in horses, and as major lameness source (Mayaki et al., 2019). In these cases, animals manifest decrease in spine flexibility, in motion range and in pulling force (Wennerstrand et al., 2004), as well some behavioral changes resulting, possibly, as effect of local pain and discomfort (Mayaki et al., 2019).

In the horse dorsal region, there are two important epaxial muscles, Longissimus dorsi (LD) and Musculus multifidus (MM) (D'Angelis et al., 2004; Stubbs et al., 2011; Oliveira et al., 2015). LD is a superficial mobilizing muscle located above dorsal and lumbar vertebrae transverse processes, promoting intervertebral joints mobilization (Clayton, 2016), spine stabilization and projection holding up the head and neck movements (Ritruechai et al., 2008), transmitting the energy generated by the back to the front legs (Stubbs and Clayton 2008) and supporting the rider weight during work (Douglas et al., 2012). Horses with muscular disorders in dorsal region show spasms in LD during physical activity and, therefore, can be observed shortening in their stride length and thoracolumbar region pain and limited flexion capacity (Clayton, 2012; Oliveira et al., 2015). 
Musculus multifidus (MM) is classified as a deep stabilizing muscle and is located medially to the LD (Oliveira et al., 2014), thus, MM plays an important role stabilizing intervertebral joints, acting as main connection between spine bones and avoiding micro movements related to joint surfaces during locomotion. Because of this, MM is also known as stabilizing muscle (Alves et al., 2007; Stubbs \& Clayton, 2008). The MM, in conjunction with abdominal muscles, is also responsible for supporting the horse's back and, consequently, provide adequate conditions to, efficiently, carry the rider (Oliveira, 2017). The lack of activity, or atrophy, of this muscle result in vertebral instability capable of promoting vertebrae pathologies, such as osteoarthritis (Freeman et al., 2010).

During physical activity, skeletal muscles are liable to several physiological changes due its adaptation to exercise, resulting in increased strength and speed as resistance to fatigue (Rivero, 2007). However, for this to occur, both morphological and metabolic changes in muscle are necessary, such as hypertrophy and increased oxidative capacity (McGivney et al., 2009).

In horses, one of the main ways to promote muscle hypertrophy is the application of training programs based on resistance exercises (Schoenfeld, 2010). These exercises are considered effective stimulators of muscle protein synthesis, stimulating the increase in the number of sarcomeres, as well improving muscle fibers size and diameter (Schoenfeld, 2010; Damas et al., 2015; Haun et al., 2019). Physical resistance exercises promote, also, enhancement in vascularization of exercised muscles (Rivero, 2007) stimulating the synthesis of contractile myofibrillar proteins, actin and myosin, (Schoenfeld, 2010; Haun et al., 2019). Consequently, increasing muscle fibers diameter result in larger cross-sectional area of the muscle (Toigo \& Boutellier 2006).

Studies have also shown that a single session of high-intensity exercise in equine athletes is adequate to modulate the genes expression related to metabolism and muscle hypertrophy, signatures of endurance and resistance exercise (McGivney et al., 2009).

The benefits of adopting a physical training program based on functional exercises have been extensively studied in recent years, as it deals with simple and non-invasive techniques using the animal's own weight to develop core stability (body central strength) (Oliveira et al., 2015). Among these benefits, can be highlighted the increased balance, elasticity and flexibility of the animals (Frick, 2010) submitted to passive stretching, promoting enlargement of the joints motion range, due the flexibility it provides (Halsberghe et al., 2017). However, according to the literature consulted, few studies addressed the effects of passive stretching on horses biomechanics. Dynamic mobilization is responsible for promoting muscle hypertrophy (D'Angelis et al., 2004; Stubbs et al., 2010; Tabor, 2015), enabling musculoskeletal disorders (Oliveira et al., 2015; Clayton, 2016) and improve, or restore, the horses range motion (Clayton et al., 2011).

Therefore, the present research aimed to evaluate the effect of adopting a program of functional exercises, over a 90day period, to measure the short, medium and long-term response on the development of epaxial musculature and linear kinematics of patrol horses.

\section{Methodology}

All experimental procedures were approved by the Ethics Committee on Animal Research of the Federal University of Sergipe under the protocol no 07/2017.

\subsection{Experimental design}

The experiment was developed at the Mounted Police Squad of the State of Sergipe (Aracaju/SE, Brazil). Eight mixedbreed geldings, with $14 \pm 3.5$ years-old and $418 \pm 50 \mathrm{~kg}$ of body weight, were used and previously evaluated for absence of any symptoms compatible with musculoskeletal disorders.

The experimental design adopted here was completely randomized. To measure short, medium and long-term response related to a functional exercises program on development of epaxial musculature and linear kinematics. Each horse was observed 
from day zero to day 90 . Therefore, data collections were made at day 0 (one day before the beginning of the exercises) to assess the short- (30 days), medium- (60 days) and long- (90 days) term responses, resulting in four repeated evaluations for each animal. In addition, each horse was considered a repetition, completing eight repetitions for each measure.

During experimental period, the horses were kept in individual stalls, where they received commercial pelleted feed and Tifton hay (Cynodon spp) offered in three daily meals, calculated in order to meet the nutritional requirements of horses submitted to light work (NRC, 2007). The mounted patrol work routine consisted of twelve hours of urban patrol activity, divided in six hours in the morning and six hours at evening, in alternate days. On rest days, the animals remained in the stalls and did not perform any type of physical activity.

The experimental physical activity consisted of functional training program, developed over 90 days. All horses were submitted to the same functional training program, and it was conducted under the supervision of a previously trained professional. Prior to each functional session, the horses warmed up for 10 minutes, guided by a halter on a sand track (Oliveira et al., 2015). The functional training program was applied three times a week, on alternate days, and consisted of dynamic mobilization, passive stretching, reflexive mobilization and dynamic imbalance exercises (Stubbs \& Clayton, 2008).

Dynamic mobilization consisted of three head movements with longitudinal cervical flexion (head on chest, head between the carpus and head between hooves), one head movement with cervical extension and three head movements with lateral cervical flexion (head on shoulder, on patella and on hock) to the right and left sides of the animal's body. After assuming the correct posture for each exercise, the horses remained in this position for five seconds, with a snack (carrot) as a stimulus (Oliveira et al., 2020). This dynamic mobilization exercises corresponded to one series; each series was repeated five times per animal, adopting 30 -second rest interval between them.

The passive stretching exercises series consisted of thoracic and pelvic limbs protraction and retraction, as well as diagonal thoracic limbs protraction (Oliveira et al., 2015). The horses were held in the stretch position for thirty seconds. Five repetitions were performed for each exercise with thirty seconds of interval between them. Also, to perform passive stretching exercises, extreme care was taken with the horses correctly located, with their limbs in adequate position to the ground and in correct balance (Hill \& Crook 2010).

Sternum lifting was the only reflexive mobilization exercise used. For this, continuous pressure was applied manually in the midventral line (sternum line), oriented to the craniocaudal line, to activate thoracic belt muscles (trapezius, serratus, subclavian and descending pectoral). Was required the animals to stay in this position for five seconds per repetition, performing five repetitions with thirty seconds of interval between each repetition.

The dynamic imbalance exercise was performed through spinning. In this case, the horses were guided by a halter to complete small circles during walk, with the aid of a barrel, in order to cross its pelvic limbs (internal pelvic limb, crossing cranially the contralateral limb). The same was done on left and right sides of each animal, adopting ten repetirions for each side, with thirty seconds of interval before change direction.

\subsection{Muscle biometrics}

The thickness (cm) of the Longissimus dorsi muscle (LD) and the total cross-sectional area $\left(\mathrm{cm}^{2}\right)$ of the Musculus multifidus (MM) was measured by ultrasound (Honda electronics HS-1500, 1.5 - $2 \mathrm{MHz}$ linear transducer and probe $12 \mathrm{~cm}$ long). The horses were housed inside the stall and trichotomy was performed in the evaluated regions, followed by local cleaning with soap and water. After preparing the skin, gel was used for ultrasound assessments.

To determine $L D$ thickness, the region between the last two thoracic vertebrae $\left(T_{17}-T_{18}\right)$ was evaluated. For evaluation of MM cross-sectional area, the area above the fifth lumbar vertebra $\left(L_{5}\right)$ (Stubbs et al., 2011). The lumbar sacral joint was located by palpation and ultrasonography, specifically, on the region between sixth lumbar $\left(\mathrm{L}_{6}\right)$ and first sacral vertebrae, as well as 
lumbar and thoracic vertebrae spinous processes, that were palpated and identified using a marker pen trough cranial direction, from $\mathrm{L}_{6}$ to $\mathrm{T}_{17}$ vertebrae.

To perform ultrasound measures, the probe was positioned transversely in relation to the dorsal midline of horse body, forming an approximate angle of $45^{\circ}$ (Oliveira et al., 2014). Two images of LD and MM on the left and right sides of horse body were obtained and saved on a computer for further analysis in IMAGEJ ${ }^{\circledR}$ software. The same professional, previously trained, was responsible for obtaining all ultrasound images throughout the experimental period.

\subsection{Kinematic evaluation}

The linear kinematic variables monitored were stride length at walk (LSW) and trot (LST), measured to verify the effects of functional exercises on horse's biomechanics. LSW and LST were defined as the distance between two consecutive footprints of the horse's left hind limb [30]. This variable was estimated using footage captured with a digital camera (Sony Cyber-Shot, DSC-H300).

Before the beginning of the kinematic analysis, the horses were warmed, submitted to a walk up for 10 minutes on a sand track. Then, they were conducted in a straight line, on sand floor, containing marker posts every meter of distance, which were later used as calibrators to calculate LSW and LST.

The camera was attached to a tripod and positioned perpendicular to the ground, five meters away from the animal. A zoom lens was used to increase the image size and to reduce parallax error effect (Clayton, 1990). In order to standardize the methodology, all filming was performed on the left side, from the sagittal plane, of the animals (Roepstorff et al., 2009).

Four videos were taken per horse, two at walk and two at trot. The digital files obtained were saved and later evaluated on a computer using Kinovea ${ }^{\circledR}$ software version 0.8 .15 . For statistical analysis, the arithmetic mean value corresponding to the two videos at walk and trot of each horse were used. To validate the measurements, previous comparisons were made between the actual distance measured in situ and the estimated distance obtained using the software.

\subsection{Statistical analysis}

The quantitative method was adopted in this study (Pereira et al., 2018). All analyzes were performed using SAS program (SAS Institute Inc., Cary, NC, USA). The Kolmogorov-Smirnov test were applied to verify that all variables were characterized with normal distribution. Arithmetic means and standard deviations were obtained for each variable studied. Analysis of variance were performed using the PROC MIXED linear model.

Analysis of variance was used to detect differences between times mean values ( $0,30,60$ and 90 days of evaluation) and, when statistical differences were detected, post hoc Tukey tests were used to determine which time differed from each other. All statistical tests used a $5 \%$ probability.

\section{Results and Discussion}

LD total cross-sectional area increased after 90 days of the beginning of the functional exercises on the right $(\mathrm{P}<0.0001)$ and left $(\mathrm{P}<0.0001)$ sides of the horses body, corresponding to an increase of, approximately, $10 \%$ and $13 \%$, respectively (Table $1)$.

MM total cross-sectional area increased in size on the left $(\mathrm{P}<0.0001)$ and right $(\mathrm{P}<0.0001)$ sides of the horses body, after the first month of evaluation. For the right side, the increase of this muscle was continuous throughout the evaluation period up to day 90 , while for the left side, continuous growth until the 60 days evaluation was observed, followed by a stabilization in the last 30 experimental days (Table 1). Furthermore, considering the entire experimental period, the increase in MM total crosssectional area was about $31 \%$ and $26 \%$, respectively for right and left sides of the horses body. 
Table 1 - Short (30 days), medium (60 days) and long (90 days) response time of the thickness (cm) of Longissimus dorsi and total cross-sectional area $\left(\mathrm{cm}^{2}\right)$ of Musculus multifidus, on the right and left sides, of patrol horses submitted to functional training*.

\begin{tabular}{|c|c|c|c|c|}
\hline \multirow{2}{*}{ Evaluation day } & \multicolumn{2}{|c|}{ Longissimus dorsi $(\mathrm{cm})$} & \multicolumn{2}{|c|}{ Musculus multifidus $\left(\mathrm{cm}^{2}\right)$} \\
\hline & Right & Left & Right & Left \\
\hline Day 0 & $6.51 \pm 0.11^{\mathrm{b}}$ & $6.67 \pm 0.15^{b}$ & $4.63 \pm 0.18^{\mathrm{d}}$ & $4.91 \pm 0.19^{c}$ \\
\hline Day 30 & $6.65 \pm 0.11^{\mathrm{b}}$ & $6.72 \pm 0.15^{\mathrm{b}}$ & $5.35 \pm 0.18^{\mathrm{c}}$ & $5.61 \pm 0.19^{b}$ \\
\hline Day 60 & $6.89 \pm 0.11^{\mathrm{b}}$ & $6.89 \pm 0.15^{\mathrm{b}}$ & $5.72 \pm 0.18^{\mathrm{b}}$ & $5.98 \pm 0.19^{\mathrm{a}}$ \\
\hline Day 90 & $7.39 \pm 0.11^{\mathrm{a}}$ & $7.39 \pm 0.15^{\mathrm{a}}$ & $6.10 \pm 0.18^{\mathrm{a}}$ & $6.19 \pm 0.19^{\mathrm{a}}$ \\
\hline$P$-value & $<0.0001$ & $<0.0001$ & $<0.0001$ & $<0.0001$ \\
\hline
\end{tabular}

$P$-value = probability; a, b, c means followed by different letters, in the column, differ from each other by the Tukey test $(\mathrm{P}<0.05) ; *$ Dynamic mobilization exercises, passive stretching, reflexive mobilization and dynamic imbalance. Source: Authors.

LSW increased $(\mathrm{P}<0.0001)$ after 60 days of experimental evaluation, this gain was continuous and reached its maximum value at 90 days. In the same context, LST differed over time $(\mathrm{P}<0.0003)$ with significant improvement found after 60 days of functional training program. At 30 days, LST decreased in relation to day 0; however, from day 60 LST showed improvement and stabilized until the last day of evaluation (Table 2).

Longissimus dorsi showed late response to functional training program, since muscle hypertrophy only occurred after 90 days (Table 1). This denotes the muscle cells ability to adapt to functional program training, resulting in muscle hypertrophy (Halsberghe et al., 2017).

Table 2 - Short (30 days), medium (60 days) and long (90 days) response time of stride length, walk and trot, of patrol horses submitted to functional training*.

\begin{tabular}{ccc}
\hline & \multicolumn{2}{c}{ Stride length $(\mathrm{cm})$} \\
\cline { 2 - 3 } Response time & Walk & Trot \\
\hline Day 0 & $174.57 \pm 12.08^{\mathrm{c}}$ & $208.69 \pm 21.23^{\mathrm{b}}$ \\
Day 30 & $169.40 \pm 8.54^{\mathrm{c}}$ & $235.85 \pm 29.34^{\mathrm{a}}$ \\
Day 60 & $193.35 \pm 22.05^{\mathrm{b}}$ & $235.39 \pm 29.11^{\mathrm{a}}$ \\
Day 90 & $207.52 \pm 22.70^{\mathrm{a}}$ & $<0.0003$ \\
\end{tabular}

$P$-value = probability; a, b, c means followed by different letters, in the column, differ from each other by the Tukey test $(\mathrm{P}<0.05) ; *$ Dynamic mobilization exercises, passive stretching, reflexive mobilization and dynamic imbalance. Source: Authors.

Research has shown that the dynamic mobilization in horses is not associated with the increase of Longissimus dorsi musculature, which is different and unprecedented to that observed in this study. Since dynamic mobilization has been proven to promote the activation of deep epaxial muscles, such as Musculus multifidus (Stubbs et al., 2011; Oliveira et al., 2015), in horses that performed only this physical activity or when the dynamic mobilization exercises were conducted with walking for 25 minutes. Therefore, LD hypertrophy in the horses of this trial must be related to the association between functional program 
(Schoenfeld, 2010) and the physical activity performed during the patrol, which are constituted by urban patrol rounds at walk for six consecutive hours, activity that requires great work of muscle endurance.

Similarly, D'Angelis et al. (2004), working with Arabian horses submitted to 90 days of treadmill aerobic training for three days a week, reported LD hypertrophy due 90 days in training. This justifies the LD depth $(6.51 \mathrm{~cm})$ obtained in the patrol horses in activity for six hours, at the beginning of the present trial (Table 1) in comparison to the same measure in equine therapy horses, submitted to activity at walk for 25 minutes $(5.40 \mathrm{~cm}$ ) (Oliveira et al., 2015). Such findings demonstrate the importance of associate dynamic mobilization with superficial musculature strengthening at thoracolumbar region in horses that, related to LD, can be observed in activities classified as for resistance or aerobic.

The short-term response observed as hypertrophy of the MM total cross-sectional area at 30 days evaluated in the present study, may have occurred because the horses had an important atrophy of the muscle in question, considering its small size at the beginning of the experimental period of $4,63 \mathrm{~cm}^{2}$, when compared to the values found in the literature of $5.40 \mathrm{~cm}^{2}$ in horse therapists (Oliveira et al., 2015), $9.10 \mathrm{~cm}^{2}$ for horses at the fundamental riding level (Stubbs et al., 2011) and 14,52 $\mathrm{cm}^{2}$ for Thoroughbred horses (Tabor, 2015). This demonstrates the effectiveness of dynamic mobilization on MM strengthening, not only in high-performance horses, but also mainly in those that do not have regular training routine.

In this sense, it is possible to infer that urban military patrolling work is not enough to promote minimum stimulation in the horses back musculature, causing MM atrophy, given the low physical demand necessary for this activity, being always performed at walk. Similar to other species, MM atrophy in horses can cause intervertebral instability (Halsberghe et al., 2017), being closely related to the emergence of severe bone vertebral pathologies (Freeman, 2010). In some cases, this vertebral instability shall persist, in athletes and work animals, if functional exercises are not applied in horses training routine, as a complementary activity, throughout animals life (Stubbs et al., 2011).

Among the exercises that constitute a functional training program are passive stretches, capable of increase horse flexibility and elasticity (Frick, 2010) and, consequently, improve its movements range (Clayton et al., 2011). Rose et al. (2009), when working with three or six weekly sessions of passive stretching in riding school horses for a period of 56 days, did not observe increase in LST. The data obtained in the present work confirms the need for a minimum period, greater than 56 days, so that the physiological adaptations can modify horse biomechanics.

Oliveira et al. (2015), when submitting hippotherapy horses to three weekly sessions of gymnastics, for 90 days, consisting of dynamic mobilization, reflexive mobilization and dynamic imbalances exercises, observed a longer stride length $(156.67 \pm 3.51 \mathrm{~cm})$ when compared to sedentary horses $(126.67 \pm 8.5 \mathrm{~cm})$ or submitted exclusively to the same dynamic mobilization exercises $(139.67 \pm 17.61 \mathrm{~cm})$. Similar to the present study, where increase in stride length values were found, from $174.57 \pm 12.08 \mathrm{~cm}$ to $207.52 \pm 22.70 \mathrm{~cm}$ on days 0 and 90 of the evaluation, respectively. It is worth mentioning that, the highest absolute values in the stride length found in Table 2, when compared to Oliveira et al. (2015), must be related to the height of the animals. In general, horses used in hippotherapy are characterized to be of medium to low height, while patrolling animals must be conformed with higher height at withers, so that they are able to perform their function properly, a trait that directly interferes with the absolute values of the stride length.

The biomechanics improvement observed in the present study, in LSW and LST, may be due to greater horse ability to move anterior and posterior limbs proximal joints, promoted by protraction and retraction activities (Eckardt and Witte 2009). The greater the projection of the posterior limb in retraction, more force will be generated (Douglas et al., 2012) that is, the greater the joint movement amplitude the greater the movement of protraction and retraction of the limbs. In addition, the action of the epaxial musculature together with the hypaxial has great importance in the locomotion of the horses (Dvorakova et al., 2009). Therefore, it can be stated that the lack of hypertrophy, as well as musculoskeletal disorders originating from intervertebral instabilities in the thoracolumbar region, are factors that can potentially modify horse's biomechanics (Clayton and Hobbs 2017). 
These biomechanical changes at walk were observed at 60 days of execution functional training, as consequence of the MM and LD muscular hypertrophies at 30 and 90 days, respectively.

\section{Conclusion}

The adoption of a regular program of functional exercises, over 90 days, promotes adaptive muscle and biomechanical responses in patrol horses. Functional exercises promote short-term hypertrophy of Musculus multifidus, increase in stride length in medium term, and in long-term causes hypertrophy of Longissimus dorsi muscle.

\section{Acknowledgments}

The authors are grateful to the Coordenação de Aperfeiçoamento de Pessoal de Nível Superior (CAPES) - Brazil, financial code 001, and to the Mounted Police Squadron (EPMon) of the State of Sergipe for the invaluable support in making available the horses used in this study.

\section{References}

Aleman, M. A. (2008) Review of equine muscle disorders. Neuromuscular disorders, 18, 277-87.

Alves, A. L. G., Fonseca, B. P. A., Thomassian, A., Nicoletti, J. L. M. \& Hussni, C. A., Silveira, A. B. (2007). Lombalgia em eqüinos. Brazilian Journal of Veterinary Research and Animal Science 1, 191-199.

Cabral, G. C., Dias, A. C. C., de Souza Tassinari, W., de Almeida, M. I. V., de Carvalho Peres, A. A. \& de Almeida, F. Q. (2020). Horse Agribusiness in Rio de Janeiro, Brazil: production diagnosis and productivity indexes of Mangalarga Marchador breeding systems. Research, Society and Development, 9 , e4329119941e4329119941.

Clayton, H. M. (1990). Gait evaluation: making the most of your home video system. American Association of Equine Practitioners, 36, 447-455.

Clayton, H. M., Lavagnino, M., Kaiser, L. J. \& Stubbs, N. C. (2011). Swing phase kinematic and kinetic response to weighting the hind pasterns. Equine Veterinary Journal, 43, 210-215.

Clayton, H. M. (2012). Equine back pain reviewed from a motor control perspective. Comparative exercise physiology, 8, $145-52$.

Clayton, H. M. (2016). Core Training and Rehabilitation in Horses. Veterinary Clinics of North America: Equine Practice, 32, 49-71.

Clayton, H. M. \& Hobbs, S. J. (2017). The role of biomechanical analysis of horse and rider in equitation science. Applied Animal Behaviour Science, 190:123132

Damas, F., Phillips, S., Vechin, F. C. \& Ugrinowitsch, C. A. (2015). Review of resistance training-induced changes in skeletal muscle protein synthesis and their contribution to hypertrophy. Sports Med, $45,801-7$.

D'Angelis, F. H. F., Mota, M. D. S., Freitas, E. V. V., Ferraz, G. C., Abrahão, A. R., Lacerda-Neto, J. C. \& Queiroz-Neto, A. (2004). Ultra-sonografia do músculo longissimus dorsi de equinos da raça Puro-sangue Árabe em treinamento de resistência associado à suplementação prolongada com creatina. Revista Brasileira de Ciências Veterinária, 12, 142-146.

Douglas, J. L., Price, M., \& Peters, D. M. (2012). A systematic review of physical fitness, physiological demands and biomechanical performance in equestrian athletes. Comparative exercise physiology, 8(1), 53-62.

Dvorakova, T., Janura, M. \& Svoboda, Z. (2009). The influence of the leader on the movement of the horse in walking during repeated hippotherapy sessions. Acta Universitatis Palackianae Olomucensis. Gymnica, 39, 43-50.

Eckardt, F. \& Witte K. (2016). Kinematic Analysis of the Rider According to Different Skill Levels in Sitting Trot and Canter. Journal of Equine Veterinary Science, 39:51-57.

Freeman, M. D., Woodham, M. A. \& Woodham, A. W. (2010). The role of the lumbar multifidus in chronic low back pain: A review. PM \& $R, 2,142-146$.

Frick, A. (2010). Stretching Exercises for Horses: Are They Effective? Journal of Equine Veterinary Science 2010; 30:50-59.

Haun, C. T., Vann, C. G., Osburn, S. C., Mumford, P. W., Roberson, P. A., Romero, M. A., Fox, C. D., Johnson, C. A., Parry, H. A., Kavazis, A. N., Moon, J. R., Badisa, V. L. D., Mwashote, B. M., Ibeanusi, V., Young, K. C. \& Roberts, M. D. (2019). Muscle fiber hypertrophy in response to 6 weeks of high-volume resistance training in trained young men is largely attributed to sarcoplasmic hypertrophy. PLoS One, $14, \mathrm{e} 0215267$.

Halsberghe, B. T., Gordon-Ross, P. \& Peterson, R. (2017). Whole body vibration affects the cross-sectional area and symmetry of the M. multifidus of the thoracolumbar spine in the horse. Equine Veterinary Education, 29, 493-499. 
Hill, C. \& Crook T. (2010). The relationship between massage to the equine caudal hindlimb muscles and hindlimb protraction. Equine Veterinary Journal, $42(38), 683-687$.

Mayaki, A. M., Intan-Shameha, A. R., Noraniza, M. A., Mazlina, M., Adamu, L. \& Abdullah, R. (2019). Clinical investigation of back disorders in horses: A retrospective study (2002-2017). Veterinary World, 12, 377-381.

McGivney, B. A., Eivers, S. S., MacHugh, D. E., MacLeod, J. N., O'Gorman, G. M., Park, S. D., Katz, L. M. \& Hill, E. W. (2009). Transcriptional adaptations following exercise in thoroughbred horse skeletal muscle highlights molecular mechanisms that lead to muscle hypertrophy. BMC Genomics, 30, 638-656.

National Research Council - NRC (2007). Nutrients Requirements of Horses. Washington: National Academy of Sciences.

Oliveira, K., Soutello, R. V. G., Fonseca, R., Lopes, A. M., Santos, P. C. S., Santos, J. M. F., Massarelli, A. C., Rodrigues, J. S. \& Vera, J. H. S. (2014). Biometria por ultrassonografia da musculatura epaxial e pélvica em equinos treinados com rédea Pessoa. Ciência Rural, 44, 2045-2051.

Oliveira, K., Soutello, R. V. G., Fonseca, R., Costa, C., Meirelles, P. R. L., Fachiolli, D. F. \& Clayton, H. M. (2015). Gymnastic training and dynamic mobilization exercises improve stride quality and increase epaxial muscle size in therapy horses. Journal of Equine Veterinary Science, 35, 888-893.

Oliveira, K. (2017). Restrição de Movimento: HorseMove método. Simplissimo.

Oliveira, K., Clayton, H. M., \& Harada, S. É. (2020). Gymnastic Training of Hippotherapy Horses Benefits Gait Quality When Ridden by Riders with Different Body Weights. Journal of Equine Veterinary Science, 94, 103248.

Pereira, A. S., Shitsuka, D. M., Parreira, F. J. \& Shitsuka, R. (2018). Metodologia da pesquisa científica. UFSM.

Ritruechai, P., Weller, R. \& Wakeling, J. M. (2008). Regionalisation of the muscle fascicle architecture in the equine longissimus dorsi muscle. Equine Veterinary Journal, 40, 246-251.

Rivero, J. L. L. (2007). A Scientific Background for Skeletal Muscle Conditioning in Equine Practice. Journal of Veterinary Medicine Series A, $54,321-332$.

Roepstorff, L., Egenvall, A., Rhodin, M., Byström, A., Johnston, C., Weeren, P. R. \& Weishaupt, M. (2009). Kinetics and kinematics of the horse comparing left and right rising trot. Equine Veterinary Journal, 41, 292-296.

Rose, N. S., Northrop, A. J., Brigden, C. V. \& Martin, J. H. (2009). Effects of a stretching regime on stride length and range of motion in equine trot. The Veterinary Journal, 181, 53-55.

Ropka-Molik, K., Stefaniuk-Szmukier, M. Z., Ukowski, K., Piórkowska, K. \& Bugno-Poniewierska, M. (2017). Exercise-induced modification of the skeletal muscle transcriptome in Arabian horses. Physiological Genomics, 49, 318 -326.

Schoenfeld, B. J. (2010). The mechanisms of muscle hypertrophy and their application to resistance training. Journal of Strength and Conditioning Research, $24,2857-72$.

Stubbs, N. C. \& Clayton, H. M. (2008). Activate your horse's core. Activate Your Horse's Core: Unmounted Exercises for Dynamic Mobility, Strength and Balance. Mason: Sport Horse Publications.

Stubbs, N. C., Riggs, C. M., Hodges, P. W., Jeffcott, L. B., Hodgson, D. R., Clayton, H. M. \& MCgowan, C. M. (2010). Osseous spinal pathology and epaxial muscle ultrasonography in thoroughbred racehorses. Equine Veterinary Journal, 38, 654-661.

Stubbs, N. C., Kaiser, L. J., Hauptman, J. \& Clayton, H. M. (2011). Dynamic mobilization exercises increase cross sectional area of musculus multifidus. Equine Veterinary Journal, 43, 522-529.

Tabor, G. (2015). The effect of dynamic mobilization exercises on the equine multifidus muscle and thoracic profile. Plymouth: Universidade de Plymouth.

Toigo, M. \& Boutellier, U. (2006). New fundamental resistance exercise determinants of molecular and cellular muscle adaptations. European Journal of Applied Physiology, 97, 643-663.

Wennerstrand, J., Johnston, C., Roethlisberger-Holm, K., Erichsen, C. \& Eksell, P., Drevemo, S. (2004). Kinematic evaluation of the back in the sport horse with back pain. Equine Veterinary Journal, 36, 707-711. 